\title{
Review
}

\section{Hematopoietic Cell and Renal Transplantation in Plasma Cell Dyscrasia Patients}

\author{
Olga Baraldi, Valeria Grandinetti, Gabriele Donati, Giorgia Comai, Giuseppe Battaglino, \\ Vania Cuna, Irene Capelli, Elisa Sala, and Gaetano La Manna
}

\begin{abstract}
Department of Experimental Diagnostic and Specialty Medicine (DIMES), Nephrology, Dialysis and Renal Transplant Unit, St Orsola Hospital, University of Bologna, Bologna, Italy
\end{abstract}

\begin{abstract}
Gammopathies, multiple myeloma, and amyloidosis are plasma dyscrasias characterized by clonal proliferation and immunoglobulin overproduction. Renal impairment is the most common and serious complication with an incidence of 20-30\% patients at the diagnosis. Kidney transplant has not been considered feasible in the presence of plasma dyscrasias because the immunosuppressive therapy may increase the risk of neoplasia progression, and paraproteins may affect the graft. However, recent advances in clinical management of multiple myeloma and other gammopathies allow considering kidney transplant as a possible alternative to dialysis. Numerous evidence indicates the direct relationship between hematological remission and renal function restoring. The combination of kidney and hematopoietic cell transplant has been reported as a promising approach to reestablish end-organ function and effectively treat the underlying disease. This review describes current protocols used to perform kidney transplantation in patients with plasma dyscrasias.
\end{abstract}

Key words: Plasma dyscrasia; Multiple myeloma (MM); Amyloidosis (AL); Hematopoietic cell transplantation; Kidney transplant

\section{INTRODUCTION}

Gammopathies, multiple myeloma (MM), and amyloidosis (AL) are plasma cell dyscrasias (PCD) characterized by clonal proliferation of plasma cells, monoclonal immunoglobulin secretion, and often renal impairment (20-30\% of patients at the diagnosis) $(2,14)$. In the past decades, the diagnosis of hematological dyscrasias discouraged kidney transplant for many reasons; the immunosuppressive therapy required for transplantation may enhance neoplasia progression and increase the risk of sepsis and infection, and paraprotein overexpression may affect the graft (25). Recently, it has been reported that novel chemotherapy combined with autologous stem cell transplantation may improve the outcome of kidney transplant in PCD patients (25). The aims of this review are to describe the current protocols for kidney transplant specifically applied in patients with MM and AL and to identify patients who may benefit from this therapeutic option.

\section{MEDLINE SEARCH PARAMETERS}

We performed a MEDLINE search to identify published articles on kidney transplantation and hematopoietic cell transplantation (HCT) in multiple myeloma or amyloidosis patients. Search terms were "multiple myeloma," "monoclonal gammopathy," "stem cell transplantation," "kidney transplantation." We chose the English language and clinical trial and case reports as the types of manuscripts. Reviews were excluded. A further selection was done by using "kidney transplantation" and "stem cell transplantation" and "multiple myeloma" or "amyloidosis." We selected 16 studies that described renal transplantation before, after, or concomitant with hematopoietic cell transplantation (Fig. 1).

\section{PLASMA CELL DYSCRASIAS}

Monoclonal Gammopathy of Undetermined Significance

Monoclonal gammopathy of undetermined significance (MGUS) is one of the most common premalignancy

Received June 27, 2014; final acceptance July 3, 2015. Online prepub date: July 8, 2015.

Address correspondence to Gaetano La Manna, M.D. Ph.D., Policlinico Universitario S. Orsola Malpighi, Pad 15, Via Massarenti, 9 , 40128 - Bologna, Università di Bologna, Bologna, Italy. Tel: +39 051 6364577; Fax +39 051 344439; E-mail: gaetano.lamanna@unibo.it 


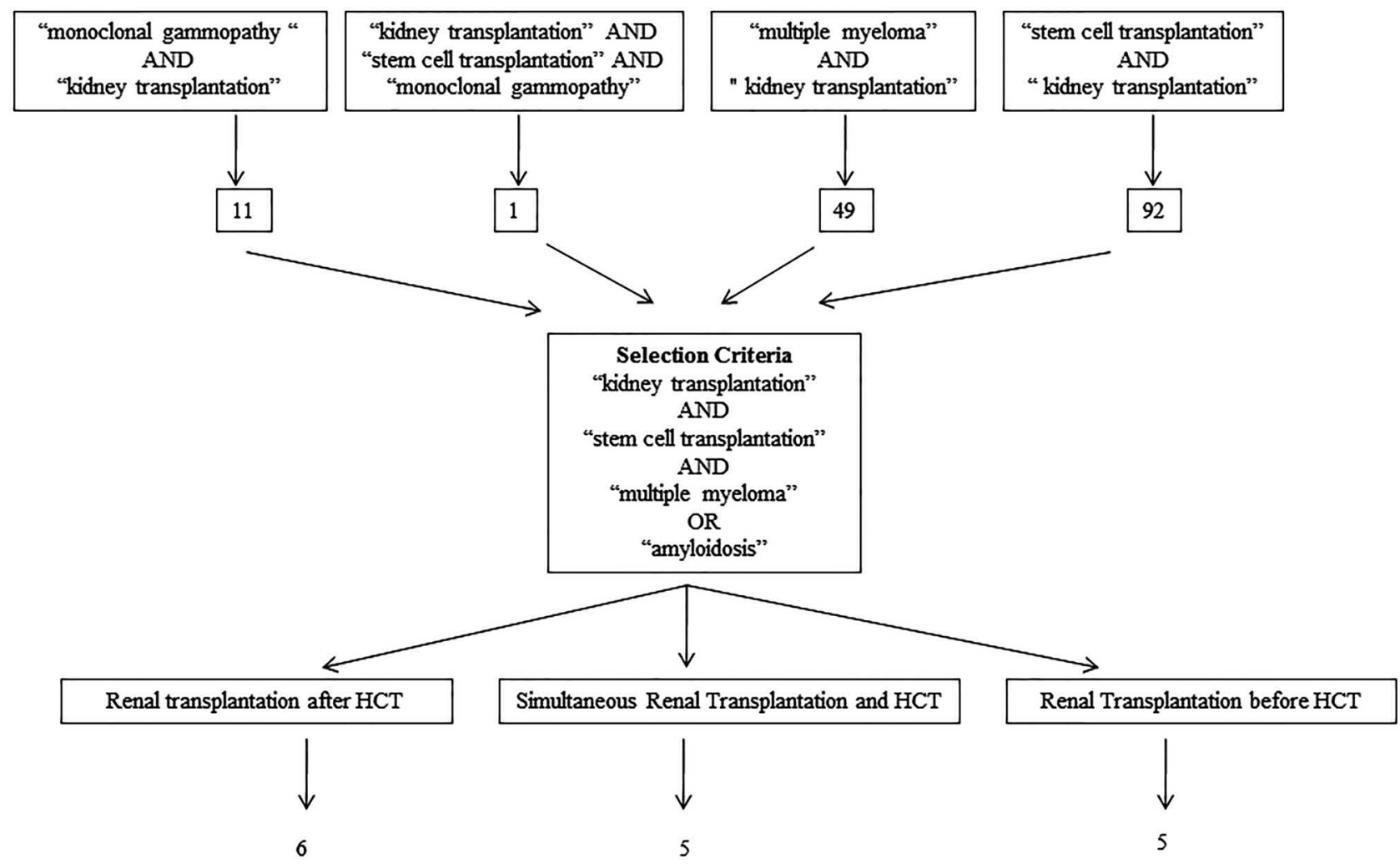

Figure 1. Terms and procedure of literature evaluation.

plasma cell dyscrasia in the Western countries (prevalence $3.2 \%$ ). Immunoglobulin (M protein) concentration less than $3 \mathrm{~g} / \mathrm{dl}$ and plasma cells in the bone marrow less than $10 \%$ are specific MGUS features, as well as the absence of hypercalcemia, renal impairment, anemia, lytic bone lesions, and any other clinical symptoms of multiple myeloma or lymphoproliferative disorders (16). MGUS is considered a prestage of multiple myeloma, and the increased ratio of $\mathrm{M}$ protein concentration and free light chains (FLCs) are predictive of a progression toward malignancy (17). The rate of malignant transformation of MGUS is $1 \%$ per year (1). Considering the high prevalence of MGUS in the general population, recipients for kidney transplantation with MGUS may be common, and therefore it is important to evaluate the risk profile in terms of rejection and MM progression for these patients. Furthermore, MGUS is often associated to renal impairment, even when the hematological disorders do not meet clinical parameters for smoldering multiple myeloma or MM in terms of malignancy. Leung et al. proposed

Table 1. Kidney Disease in Multiple Myeloma

\begin{tabular}{lcc}
\hline Renal Disease & Molecular Mechanism & Cause and Related Syndromes \\
\hline $\begin{array}{l}\text { Tubulointerstitial lesions cast } \\
\text { nephropathy (40-63\%) }\end{array}$ & $\begin{array}{c}\text { Glomerular filtration and deposi- } \\
\text { tion of free light chains leading to } \\
\text { distal obstruction }\end{array}$ & $\begin{array}{c}\text { Dehydration, hypercalcemia, contrast medium usage, } \\
\text { nephrotoxic medications (NSAIDs, diuretics, angiotensin- } \\
\text { converting enzyme inhibitors, angiotensin II receptor } \\
\text { blockers); acute kidney failure }\end{array}$ \\
$\begin{array}{c}\text { Monoclonal immunoglobulin } \\
\text { deposition disease (19-26\%) }\end{array}$ & $\begin{array}{c}\text { Deposition of light and/or heavy } \\
\text { chains in the basement membranes } \\
\text { of the glomeruli and tubules } \\
\text { AL amyloidosis (7-30\%) }\end{array}$ & $\begin{array}{c}\text { Nephrotic syndrome and progressive chronic kidney } \\
\text { damage }\end{array}$ \\
& $\begin{array}{l}\text { Proteinaceous material deposition in } \\
\text { the mesangium, glomerular base- } \\
\text { ment membranes, blood vessels }\end{array}$ & $\begin{array}{c}\text { Nephrotic syndrome and progressive chronic kidney } \\
\text { disease, often associated with a systemic involvement }\end{array}$ \\
\hline
\end{tabular}

NSAIDs, nonsteroidal anti-inflammatory drugs. 


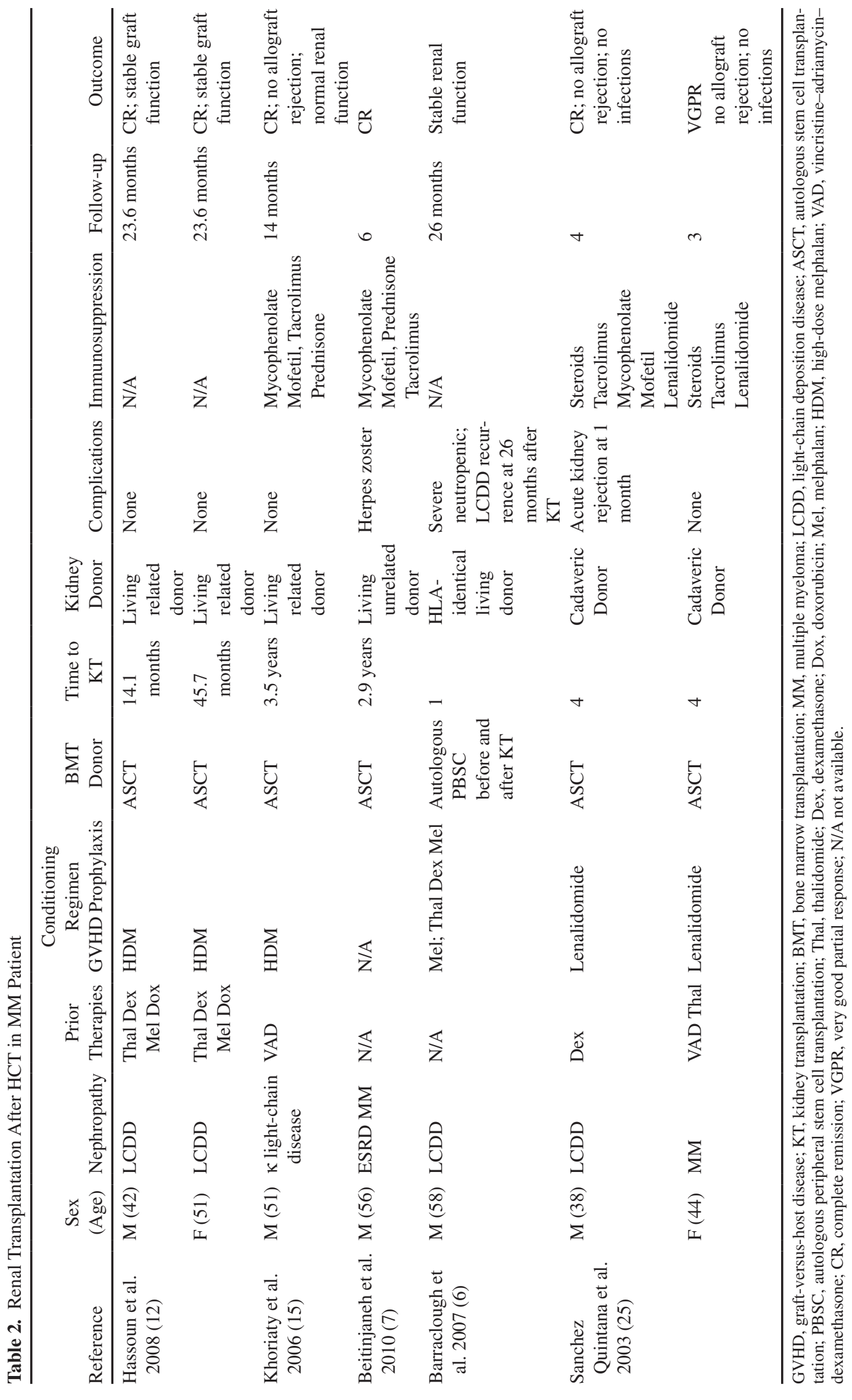


a novel definition "monoclonal gammopathy with renal significance" to discriminate these pathological features from true MGUS (18).

\section{Multiple Myeloma}

Kidney disease in MM is mainly caused by conditions summarized in Table 1. The light chain cast, nephropathy, is the most common kidney disease and affects 32-48\% of patients who died from MM (21). Histologically, myeloma-dependent cast nephropathy (MCN) shows intratubular light chain casts in distal tubules and collecting ducts. Casts are aggregates of monoclonal FLCs and Tamm Horsfall proteins (THPs). In normal conditions, FLCs are reabsorbed in proximal tubules via receptormediated endocytosis after glomerular filtration. In MM, the excess of FLCs overwhelms the capacity of proximal tubules to endocytose them, and monoclonal FLCs pass into the loop of Henle and interact with THPs. The FLC CD3 region binds THP carbohydrate chains and forms aggregates. Several factors such as urinary concentration of light chains, $\mathrm{pH}$, urine flow rate, sodium chloride, and calcium concentrations may favor FLC-THP aggregation (21). Tubule obstructions induce strong inflammation, nuclear factor $\kappa$-light chain enhancer of activated $B$ cell $(\mathrm{NF}-\kappa \mathrm{B})$ activation and production of monocyte chemoattractant protein 1 (MCP-1) and interleukin-6 (IL-6) (21).
A giant cell reaction is frequently observed around the casts where mononuclear cells are recruited, and this inflammatory response damages tubules (21). Bortezomib or thalidomide treatment and/or use of a high cutoff dialyzer are suggested in these patients to drastically reduce serum FLC levels. The combination of bortezomib and serial plasma exchange resulted in complete or partial renal response, remarkably reversing the acute renal failure secondary to cast nephropathy in MM newly diagnosed and relapsed patients (10). MCN becomes a medical emergency when patients are forced to undergo chronic dialysis. Although renal transplant is not recommended in the presence of MM because of poor prognosis, there are some cases of patients who underwent renal transplant and were in remission reported in the literature.

\section{Monoclonal Immunoglobulin Deposition Disease}

Monoclonal immunoglobulin deposition diseases (MIDDs) include light chain deposition disease (LCDD), light-heavy chain deposition disease (LHCDD), and heavy chain deposition disease (HCDD). MIDDs are characterized by amorphous to granular deposition of monoclonal immunoglobulin or its components. When the $\beta$ edges in the complementary determining region 2 (CDR2) of light chains are exposed, light chains spontaneously aggregate into oligomers and fibrils and contribute to deposition.

Table 3. Renal Transplantation After HCT in Amyloidosis Patients

\begin{tabular}{|c|c|c|c|c|c|c|c|c|c|}
\hline Reference & $\begin{array}{c}\text { Sex } \\
\text { (Age) }\end{array}$ & $\begin{array}{c}\text { Prior } \\
\text { Therapies }\end{array}$ & $\begin{array}{l}\text { Conditioning } \\
\text { Regimen } \\
\text { GVHD } \\
\text { Prophylaxis }\end{array}$ & $\begin{array}{l}\text { BMT } \\
\text { Donor }\end{array}$ & $\begin{array}{l}\text { Kidney } \\
\text { Donor }\end{array}$ & Complications & Immunosuppression & $\begin{array}{c}\text { Follow-up } \\
\text { (Months) }\end{array}$ & Outcome \\
\hline \multirow[t]{6}{*}{$\begin{array}{l}\text { Herrmann } \\
\text { et al. } 2011 \\
\text { (13) }\end{array}$} & F (62) & None & Mel & ASCT & $\begin{array}{l}\text { Living } \\
\text { related } \\
\text { donor }\end{array}$ & None & $\begin{array}{l}\text { Thymo tacrolimus, } \\
\text { mycophenolate mofetil } \\
\text { (MMF) corticosteroids }\end{array}$ & 53 & $\begin{array}{l}\text { CR; KTx } \\
\text { survival } 42.4 \\
\text { months }\end{array}$ \\
\hline & $\mathrm{F}(55)$ & None & Mel & ASCT & $\begin{array}{l}\text { Living } \\
\text { related } \\
\text { donor }\end{array}$ & None & $\begin{array}{l}\text { Basiliximab, tacrolimus, } \\
\text { mycophenolate mofetil } \\
\text { (MMF) corticosteroids }\end{array}$ & 41 & $\begin{array}{l}\text { CR; KTx } \\
\text { survival } 41.4 \\
\text { months; } \\
\text { cause of } \\
\text { death: stroke }\end{array}$ \\
\hline & M (57) & None & Mel & ASCT & $\begin{array}{c}\text { Cadaveric } \\
\text { donor }\end{array}$ & Cellular KTx & $\begin{array}{l}\text { Daclizumab, tacrolimus, } \\
\text { mycophenolate mofetil } \\
\text { (MMF corticosteroids }\end{array}$ & 39 & $\begin{array}{l}\text { CR; KTx } \\
\text { survival } 33.9 \\
\text { months }\end{array}$ \\
\hline & M (37) & None & Mel & ASCT & $\begin{array}{l}\text { Living } \\
\text { related } \\
\text { donor }\end{array}$ & $\begin{array}{l}\text { Borderline } \\
\text { KTx }\end{array}$ & $\begin{array}{l}\text { Basiliximab, tacrolimus, } \\
\text { mycophenolate mofetil } \\
\text { (MMF) corticosteroids }\end{array}$ & 39 & $\begin{array}{l}\text { CR; KTx } \\
\text { survival } 60.5 \\
\text { months }\end{array}$ \\
\hline & $\mathrm{F}(35)$ & None & Mel & ASCT & $\begin{array}{l}\text { Living } \\
\text { related } \\
\text { donor }\end{array}$ & None & $\begin{array}{l}\text { Basiliximab, tacrolimus, } \\
\text { mycophenolate mofetil } \\
\text { (MMF) corticosteroids }\end{array}$ & 75 & $\begin{array}{l}\text { PR; KTx } \\
\text { survival } 23.1 \\
\text { months }\end{array}$ \\
\hline & M (53) & None & Mel & ASCT & $\begin{array}{l}\text { Living } \\
\text { related } \\
\text { donor }\end{array}$ & None & $\begin{array}{l}\text { Thymo tacrolimus, } \\
\text { mycophenolate mofetil } \\
\text { (MMF) corticosteroids }\end{array}$ & 64 & $\begin{array}{l}\text { CR; KTx } \\
\text { survival } 10.4 \\
\text { months }\end{array}$ \\
\hline
\end{tabular}

GVHD, graft-versus-host disease; BMT, bone marrow transplantation; KT, kidney transplantation; Mel, melphalan; ASCT, autologous stem cell transplantation; CR, complete remission; PR, partial remission. Time to kidney transplantation was not available. 
The main histological lesion observed in two thirds of MIDD cases is a nodular mesangial sclerosis; mesangial sclerosis without nodules and with membranoproliferative features has also been described.

\section{AL Amyloidosis}

Amyloid light chain (AL) amyloidosis is a systemic disease characterized by extracellular deposition of congophilic fibrils in soft tissue. Amyloid is constituted by immunoglobulin or its components and appears as amorphous periodic acid Schiff-negative and silver-negative deposits in kidney biopsy. These deposits can be found mainly in vessel walls, in the glomeruli, and in tubular interstitium (22).

\section{HEMATOPOIETIC CELL TRANSPLANT (HCT)}

The gold standard treatment of plasma cell dyscrasias is high-dose melphalan followed by autologous stem cell transplantation (ASCT), even during renal failure (27). According to the National Comprehensive Cancer Network (NCCN) guidelines, the primary therapeutic options for transplant candidates include bortezomib/dexamethasone, bortezomib/doxorubicin/dexamethasone, bortezomib/ thalidomide/dexamethasone, and lenalidomide/dexamethasone (3). These approaches are followed by hematopoietic cell transplantation (HCT) and addressed to patients younger than 65 years without renal dysfunction (24). For older patients with chronic nephropathy, reduced-intensity conditioning regimens and ASCT should be recommended. The use of bortezomib or lenalidomide, before or after autologous transplantation, significantly increases complete remission rate and progression-free survival (24).

Another possible approach may be the combination of high-dose chemotherapy and ASCT followed by reducedintensity conditioning allo-SCT. This procedure has decreased treatment-related mortality to $15 \%$ or less (8). Evidence about higher safety of tandem transplantation compared to single hematopoietic cell transplant is lacking, and the risk of death and adverse events is still high (7).

In patients with PCD-related chronic nephropathy, the severity of renal dysfunction does not affect the response to chemotherapy. However, autologous stem cell transplant induces complete remission and longer survival than chemotherapy (23). Numerous retrospective studies describe the efficiency of hematopoietic cell transplant even in advanced renal failure that requires kidney transplantation. Regression of renal damage after 4-5 months from ASCT has been also reported (23).

\section{RENAL TRANSPLANTATION AFTER HCT}

Kidney transplant after HCT may be a favorable therapeutic approach, especially in dialytic younger patients with a good performance status. Considerable evidence indicates that HCT improves the quality of life and offers higher survival rate than dialysis in patients with myelomarelated end-stage renal disease (ESRD) (25).

Five studies $(6,7,12,15,25)$ describe seven patients undergoing renal transplantation after HCT (Table 2). Five patients received kidneys for transplantation from matched living related donors and two from cadaveric donors. Time between HCT and renal transplantation ranged from 14.1 months to 4 years. Follow-up ranged from 14.3 months to 6 years. In four patients chronic immunosuppression therapy was based on prednisone, tacrolimus, mycophenolate, and in two cases on lenalidomide. Acute kidney rejection at 1 month from kidney transplantation was reported in one patient efficiently treated with steroids. Recurrence of light chain deposition 26 months after renal transplant was also described. During follow-up, complete remission and renal function restoration were observed. Noteworthy, the graft rejection rate did not increase when the kidney donor was different from the HCT donor. Similar results were described in patients with amyloidosis-related nephropathy (13) (Table 3).

\section{SIMULTANEOUS HCT AND RENAL TRANSPLANT}

Table $4(9,11,23,26)$ shows results from 16 PCD patients treated with nonmyeloablative conditioning and combined kidney and bone marrow transplantation from human leukocyte antigen (HLA)-haploidentical-related donors. Fifteen patients received a conditioning regimen based on cyclophosphamide, anti-thymocyte globulin and thymic irradiation; one patient received cyclophosphamide and melphalan. Follow-up ranged from 2.4 months to 12.1 years. Ten patients showed chimerism; in seven patients a mixed lymph-hematopoietic chimerism (donor cells were $>1 \%$ of recipient's cell population) was observed, and three patients achieved full donor chimerism (100\% blood cells of recipients derived from donor). Two patients died; one from basal disease progression and one from therapy-related acute myeloid leukemia. Nine out of 16 patients achieved durable complete remission (CR), three a prolonged partial remission (PR), and four patients experienced disease progression. Six patients developed graft-versus-host disease (GVHD), thus requiring immunosuppressive therapy; one had acute cellular rejection of the kidney transplant. Ten patients maintained a stable tolerance to the kidney graft without immunosuppression. This result was partially attributable to mixed lymphohematopoietic chimerism that guaranteed better outcomes than full chimerism. It is remarkable that transplantation tolerance was achieved in patients who had only transient donor hematopoietic chimerism.

Therefore, nonmyeloablative conditioning followed by combined kidney-bone marrow transplantation from HLA-haploidentical-related donors may be considered as a potentially long-term beneficial option. A conditioning 

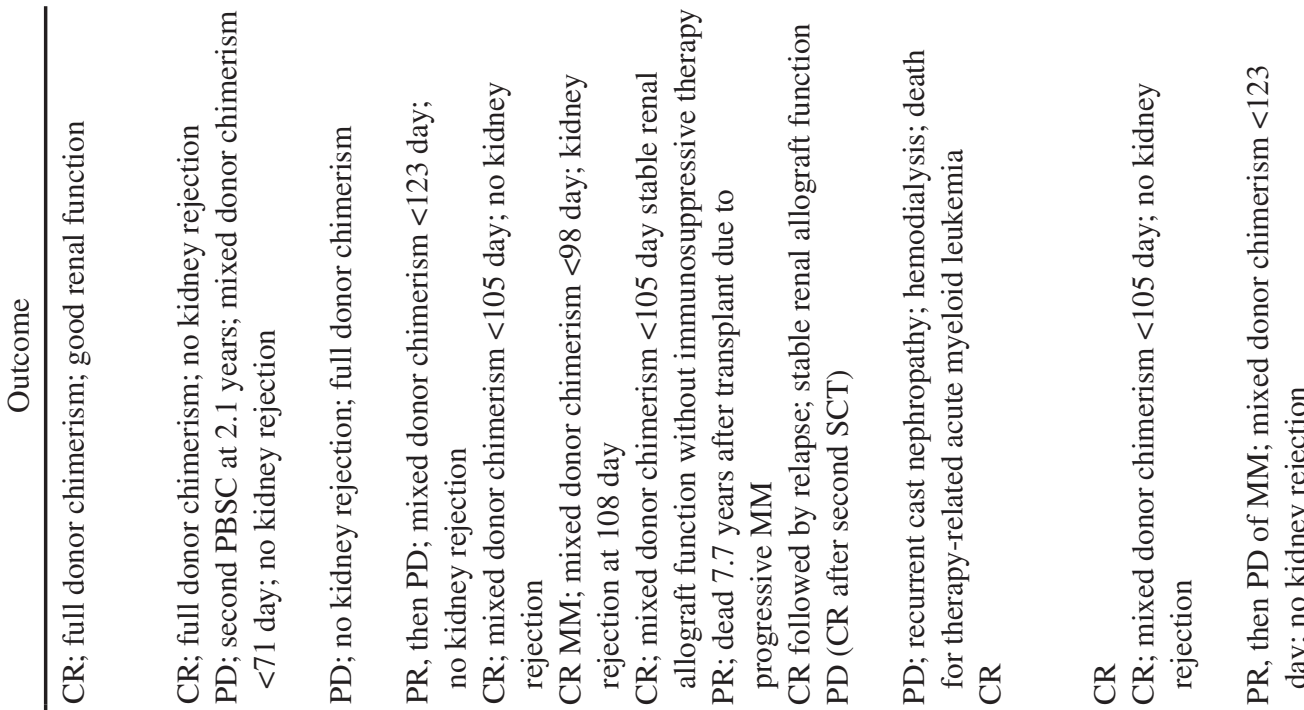

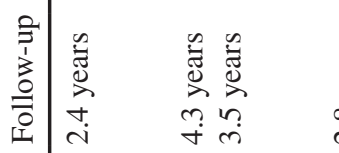

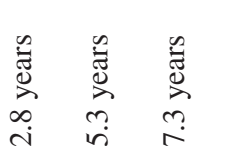

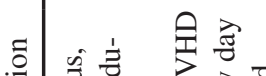

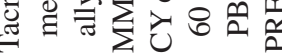

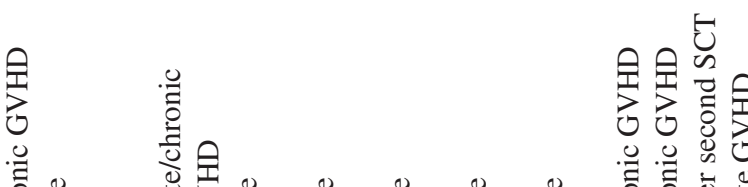

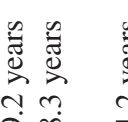

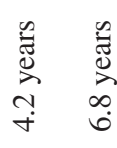

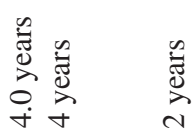

里

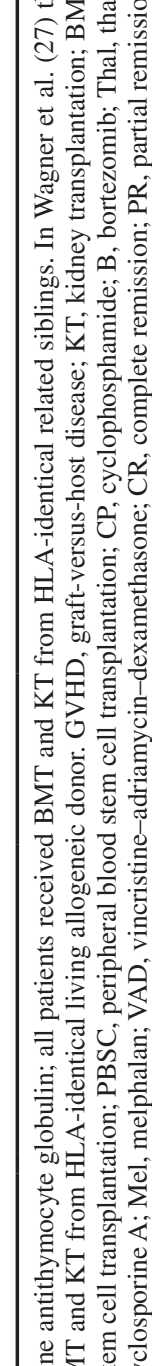

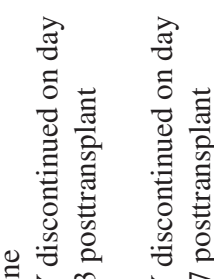

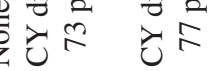




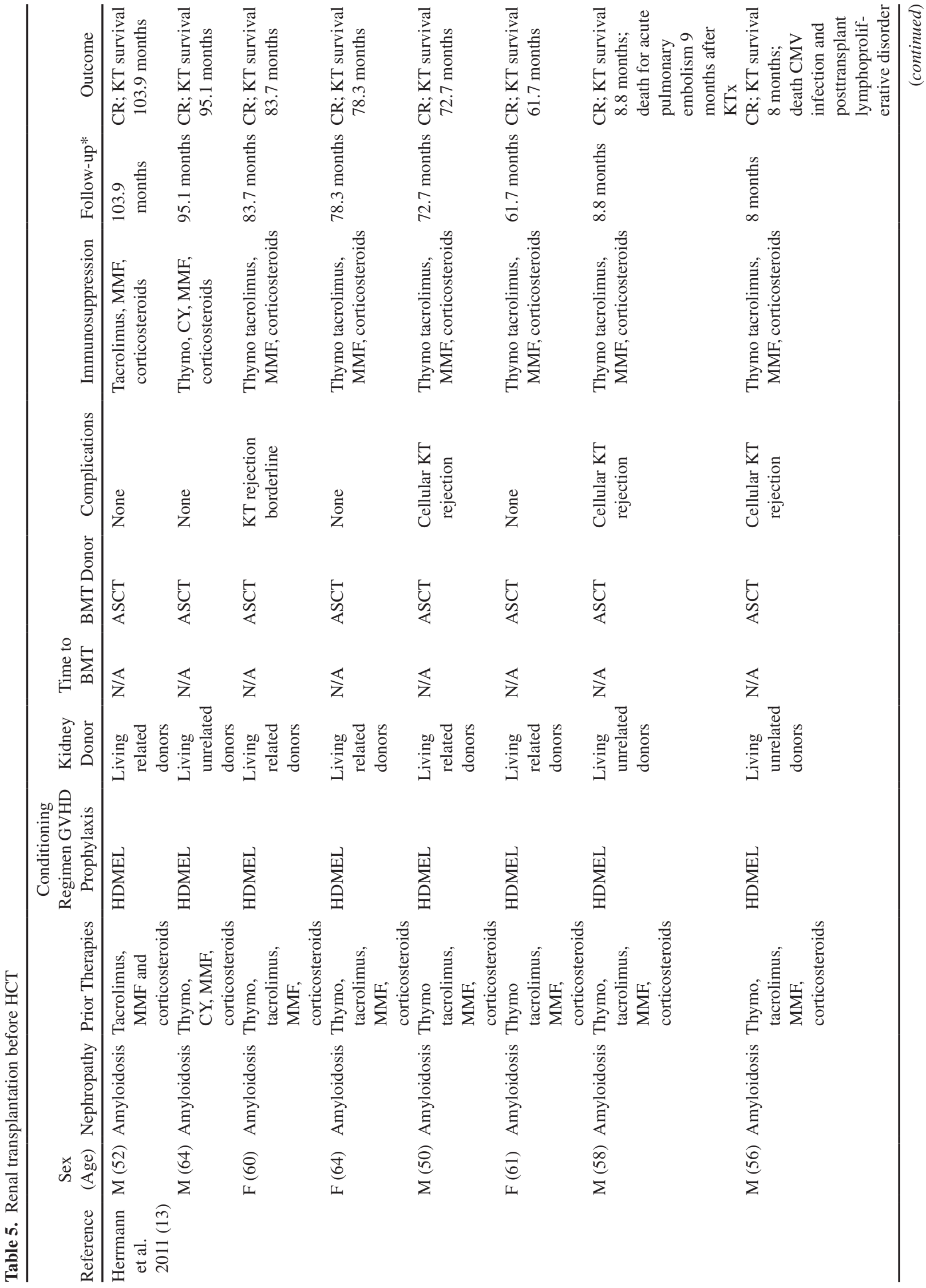




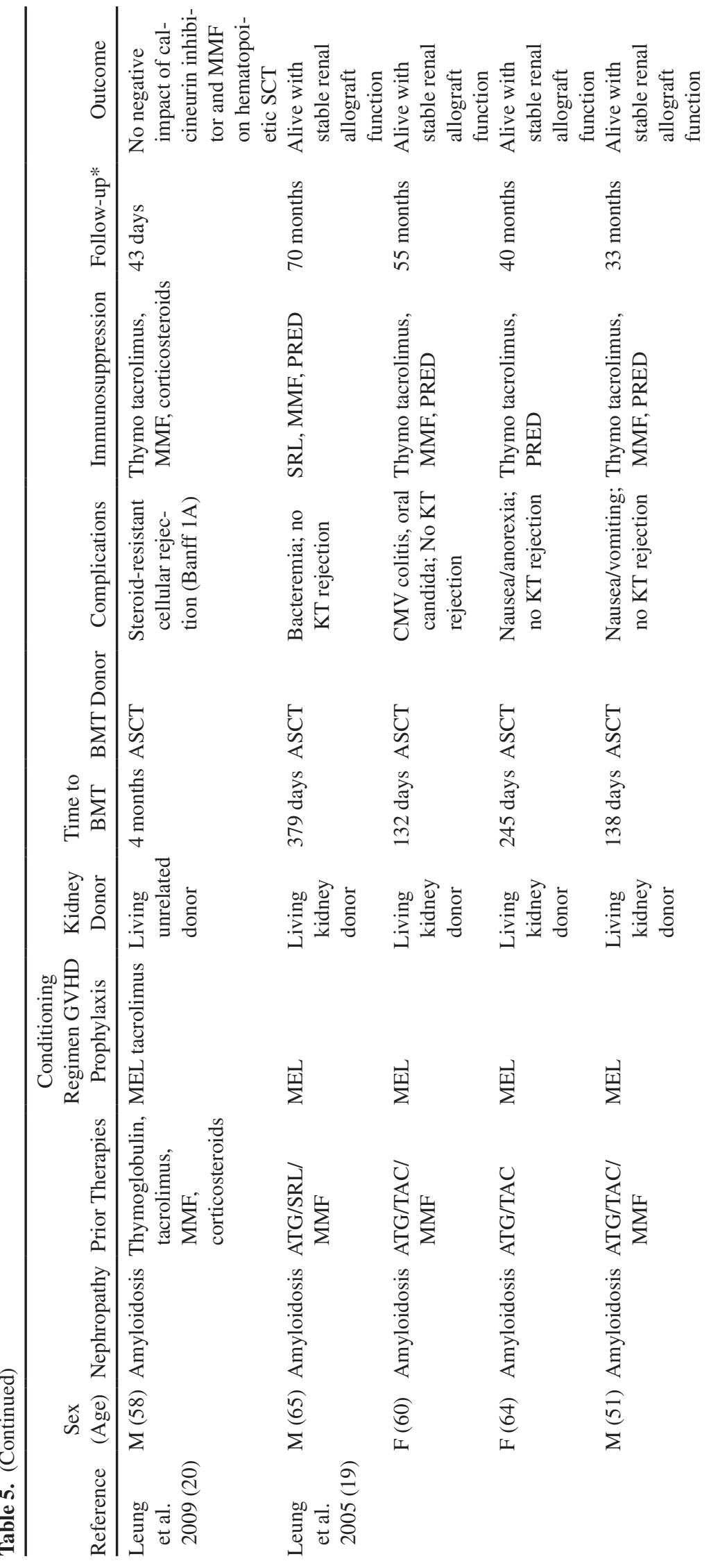




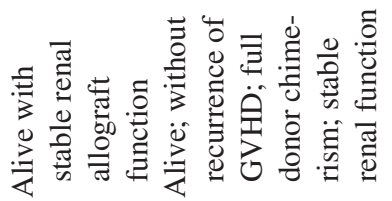

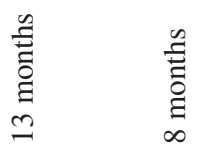

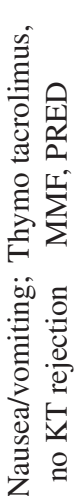

乙

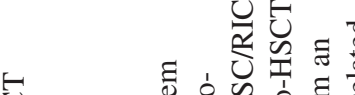

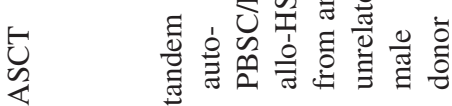

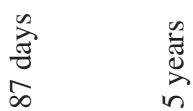

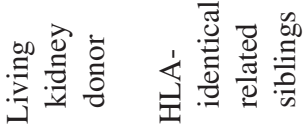

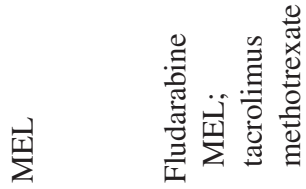

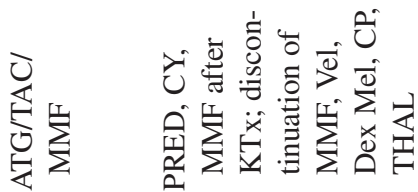

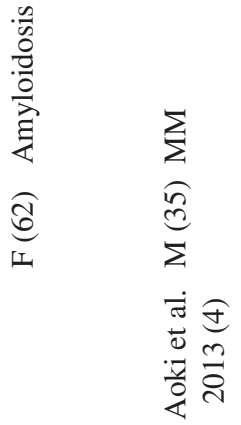

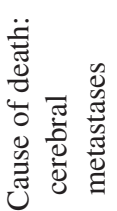

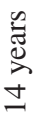

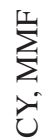

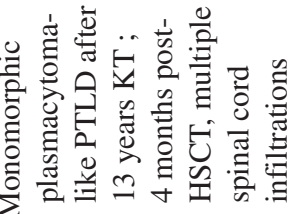

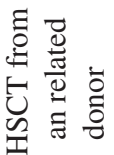

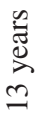

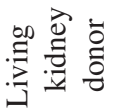
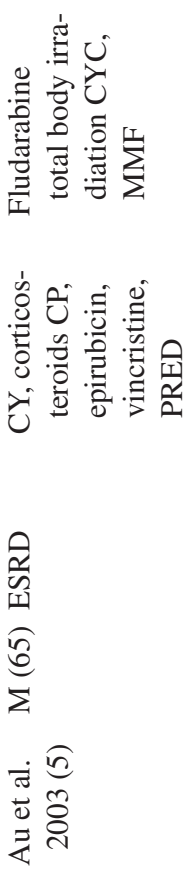

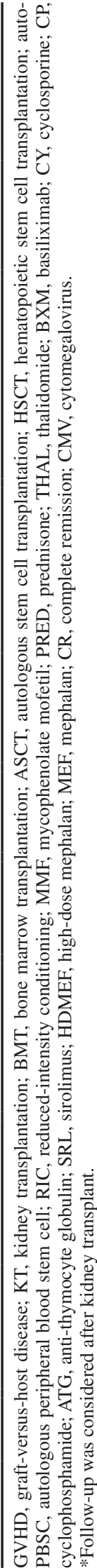


regimen with reduced toxicity may improve renal allograft tolerance and diminish the need of long-term immunosuppression (11).

\section{RENAL TRANSPLANTATION BEFORE HCT}

In five studies kidney transplantation from living donor before autologous ASCT has been described $(4,5,13,19,20)$ (Table 5). Out of 16 patients, 14 had amyloidosis-related ESRD, one MM-related ESRD, and one primary ESRD. Follow-up ranged from 43 days to 103.9 months. Time between renal transplantation and HCT ranged from 87 days to 13 years. In patients with amyloidosis, immunosuppressive therapy after transplant was calcineurin inhibitors + mycophenolate mofetil + steroids. Five patients had acute cellular rejection with a higher tendency for graft rejection in patients who received renal transplant after HCT. All patients had complete remission from amyloidosis and stable renal function. Out of 16 patients, three died of cardiovascular complications (one acute pulmonary embolism 9 months after kidney transplantation) and two of neoplasia (one posttransplant lymphoproliferative disorder and one brain metastases). Therefore, renal transplant followed by a high dose of melphalan and ASCT represents an effective treatment for AL amyloidosis with a good hematological response and an improved median survival $(13,21)$. In MM patients, the effectiveness of tandem autoperipheral blood cell transplantation/ reduced-intensity conditioning (PBSC/RIC) allo-HCT after renal transplantation remains unclear.

\section{CONCLUSION}

Renal impairment is detrimental both in multiple myeloma and in gammopathies and is often associated with morbidity and mortality. Several studies have highlighted that renal and hematopoietic transplantation from the same donor could restore organ function and efficiently treat the underlying disease. In particular, the transient mixed chimerism after combined kidney and hematopoietic cell transplantation allows the withdrawal from all immunosuppressive therapy, thus favoring normal graft functioning. Sequential living donor kidney transplant followed by autologous ASCT after conditioning with melphalan seems to be the most effective treatment for amyloidosis in ESRD patients.

Therefore, the combination of chemotherapy/ASCT and kidney transplant is pivotal to pursue renal restoration and improve the overall survival rate. The introduction of high cutoff dialyzers might further facilitate FLC removal and partially overcome renal impairment. Understanding the molecular mechanism of each renal pathological pattern is critical to choose the best strategy to manage kidney transplant in these patients. General health conditions and type of hematological dyscrasia have to be considered to select those patients who may benefit most from kidney transplant (i.e., young patients who can better tolerate a high dose of melphalan). The need of kidney transplant in multiple myeloma patients remains high, especially in those patients who present some degree of persistent chronic kidney disease after all therapeutic options described above have been exhausted. Future strategies will optimize the protocol to reduce immunoglobulin production and preserve renal function as early as possible after the diagnosis of gammopathy in order to prevent further renal damage. Further large prospective studies to identify novel strategies to manage renal and hematopoietic cell transplantation in ESRD patients should be encouraged.

ACKNOWLEDGMENT: The authors declare no conflicts of interest.

\section{REFERENCES}

1. Agarwal, A.; Ghobrial, I. M. Monoclonal gammopathy of undetermined significance and smoldering multiple myeloma: A review of the current understanding of epidemiology, biology, risk stratification, and management of myeloma precursor disease. Clin. Cancer Res. 19(5):985994; 2013.

2. Al-Hussain, T.; Hussein, M. H.; Al Mana, H.; Akhtar, M. Renal involvement in monoclonal gammopathy. Adv. Anat. Pathol. 22(2):121-134; 2015.

3. Anderson, K. C.; Alsina, M.; Bensinger, W.; Biermann, J. S.; Cohen, A. D.; Devine, S.; Djulbegovic, B.; Faber, E. A., Jr.; Gasparetto, C.; Hernandez-Illizaliturri, F.; Huff, C. A.; Kassim, A.; Krishnan, A. Y.; Liedtke, M.; Meredith, R.; Raje, N.; Schriber, J.; Singhal, S.; Somlo, G.; StockerlGoldstein, K.; Treon, S. P.; Weber, D.; Yahalom, J.; Yunus, F.; Shead, D. A.; Kumar, R. Multiple myeloma, version 1.2013. J. Natl. Compr. Canc. Netw. 11(1):11-17; 2013.

4. Aoki, T.; Kasai, M.; Harada, Y.; Matsubara, E.; Morishita, T.; Suzuki, T.; Tsujita, M.; Goto, N.; Katayama, A.; Watarai, Y.; Uchida, K.; Ito, M.; Saji, H.; Tsuzuki, T.; Uchida, T.; Ogura, M. Stable renal engraftment in a patient following successful tandem autologous/reduced-intensity conditioning allogeneic transplantation for treatment of multiple myeloma with del(17p) that developed as a post-transplantation lymphoproliferative disease following renal transplantation. Int. J. Hematol. 98(1):129-134; 2013.

5. Au, W. Y.; Lie, A. K.; Chan, E. C.; Pang, A.; Ma, S. K.; Choy, C.; Kwong, Y. L. Treatment of postrenal transplantation lymphoproliferative disease manifesting as plasmacytoma with nonmyeloablative hematopoietic stem cell transplantation from the same kidney donor. Am. J. Hematol. 74(4):283-296; 2003.

6. Barraclough, K. A.; Dowling, J. P.; Schwarer, A. P.; Perry, G. J. Sequential autologous peripheral blood stem cell transplantation and kidney transplantation of light chain deposition disease. Nephrol. Dial. Transplant. 22(4):12681269; 2007.

7. Beitinjaneh, A.; Burns, L. J.; Majhail, N. S. Solid organ transplantation in survivors of hematopoietic cell transplantation: a single institution case series and literature review. Clin. Transplant. 24(4):E94-E102; 2010.

8. Bjorkstrand, B.; Iacobelli, S.; Hegenbart, U.; Gruber, A.; Greinix, H.; Volin, L.; Narni, F.; Musto, P.; Beksac, M.; Bosi, A.; Milone, G.; Corradini, P.; Goldschmidt, H.; 
de Witte, T.; Morris, C.; Niederwieser, D.; Gahrton, G. Tandem autologous/reduced-intensity conditioning allogeneic stem-cell transplantation versus autologous transplantation in myeloma: Long-term follow-up. J. Clin. Oncol. 29(22):3016-3022; 2011.

9. Buhler, L. H.; Spitzer, T. R.; Sykes, M.; Sachs, D. H.; Delmonico, F. L.; Tolkoff-Rubin, N.; Saidman, S. L.; Sackstein, R.; McAfee, S.; Dey, B.; Colby, C.; Cosimi, A. B. Induction of kidney allograft tolerance after transient lymphohematopoietic chimerism in patients with multiple myeloma and end-stage renal disease. Transplantation 74(10):1405-1409; 2002.

10. Burnette, B. L.; Leung, N.; Rajkumar, S. V. Renal improvement in myeloma with bortezomib plus plasma exchange. N. Engl. J. Med. 364(24):2365-2366; 2011.

11. Fudaba, Y.; Spitzer, T. R.; Shaffer, J.; Kawai, T.; Fehr, T.; Delmonico, F.; Preffer, F.; Tolkoff-Rubin, N.; Dey, B. R.; Saidman, S. L.; Kraus, A.; Bonnefoix, T.; McAfee, S.; Power, K.; Kattleman, K.; Colvin, R. B.; Sachs, D. H.; Cosimi, A. B.; Sykes, M. Myeloma responses and tolerance following combined kidney and nonmyeloablative marrow transplantation: in vivo and in vitro analyses. Am. J. Transplant. 6(9):2121-2133; 2006.

12. Hassoun, H.; Flombaum, C.; D’Agati, V. D.; Rafferty, B. T.; Cohen, A.; Klimek, V. M.; Boruchov, A.; Kewalramani, T.; Reich, L.; Nimer, S. D.; Comenzo, R. L. High-dose melphalan and auto-SCT in patients with monoclonal Ig deposition disease. Bone Marrow Transplant. 42(6):405-412; 2008.

13. Herrmann, S. M.; Gertz, M. A.; Stegall, M. D.; Dispenzieri, A.; Cosio, F. C.; Kumar, S.; Lacy, M. Q.; Dean, P. G.; Prieto, M.; Zeldenrust, S. R.; Buadi, F. K.; Russell, S. J.; Nyberg, S. L.; Hayman, S. R.; Dingli, D.; Fervenza, F. C.; Leung, N. Long-term outcomes of patients with light chain amyloidosis (AL) after renal transplantation with or without stem cell transplantation. Nephrol. Dial. Transplant. 26(6):2032-2036; 2011

14. Kapoulas, S.; Raptis, V.; Papaioannou, M. New aspects on the pathogenesis of renal disorders related to monoclonal gammopathies. Nephrol. Ther. 11(3):135-143; 2015.

15. Khoriaty, R.; Otrock, Z. K.; Medawar, W. A.; Khauli, R. B.; Bazarbachi, A. A case of successful double sequential bone marrow and kidney transplantations in a patient with multiple myeloma. Nephrol. Dial. Transplant. 21(12):3585$3588 ; 2006$

16. Kyle, R. A.; Rajkumar, S. V. Monoclonal gammopathy of undetermined significance and smoldering multiple myeloma. Curr. Hematol. Malig. Rep. 5(2):62-69; 2010.
17. Landgren, O.; Kyle, R. A.; Pfeiffer, R. M.; Katzmann, J. A.; Caporaso, N. E.; Hayes, R. B.; Dispenzieri, A.; Kumar, S.; Clark, R. J.; Baris, D.; Hoover, R.; Rajkumar, S. V. Monoclonal gammopathy of undetermined significance (MGUS) consistently precedes multiple myeloma: a prospective study. Blood 113(22):5412-5417; 2009.

18. Leung, N.; Bridoux, F.; Hutchison, C. A.; Nasr, S. H.; Cockwell, P.; Fermand, J. P.; Dispenzieri, A.; Song, K. W.; Kyle, R. A.; International Kidney and Monoclonal Gammopathy Research Group. Monoclonal gammopathy of renal significance: when MGUS is no longer undetermined or insignificant. Blood 120(22):4292-4295; 2012.

19. Leung, N.; Dispenzieri, A.; Fervenza, F. C.; Lacy, M. Q.; Villicana, R.; Cavalcante, J. L.; Gertz, M. A. Renal response after high-dose melphalan and stem cell transplantation is a favorable marker in patients with primary systemic amyloidosis. Am. J. Kidney Dis. 46(2):270-277; 2005.

20. Leung, N.; Gloor, J. M.; Dean, P. G.; Lacy, M. Q.; Porrata, L. F.; Griffin, M. D. Acute cellular rejection in a renal allograft immediately following leukocyte engraftment after auto-SCT. Bone Marrow Transplant. 43(4):345-346; 2009.

21. Leung, N.; Nasr, S. H. Myeloma-related kidney disease. Adv. Chronic Kidney Dis. 21(1):36-47; 2014.

22. Leung, N.; Nasr, S. H.; Sethi, S. How I treat amyloidosis: The importance of accurate diagnosis and amyloid typing. Blood 120(16):3206-3213; 2012.

23. Nayak, L.; Lazarus, H. M. Renal allografts in plasma cell myeloma hematopoietic cell graft recipients: On the verge of an explosion? Bone Marrow Transplant. 48(3):338-345; 2013.

24. Palumbo, A.; Anderson, K. Multiple myeloma. N. Engl. J. Med. 364(11):1046-1060; 2011.

25. Sanchez Quintana, A.; Rull, P. R.; Atienza, J. B.; McDonnell, C. N. Renal transplant in plasma cell dyscrasias with lenalidomide treatment after autologous stem cell transplantation. Nephrology (Carlton) 18(9):641-643; 2013.

26. Spitzer, T. R.; Sykes, M.; Tolkoff-Rubin, N.; Kawai, T.; McAfee, S. L.; Dey, B. R.; Ballen, K.; Delmonico, F.; Saidman, S.; Sachs, D. H.; Cosimi, A. B. Long-term follow-up of recipients of combined human leukocyte antigen-matched bone marrow and kidney transplantation for multiple myeloma with end-stage renal disease. Transplantation 91(6):672-676; 2011.

27. Wagner, L.; Lengyel, L.; Mikala, G.; Remenyi, P.; Piros, L.; Csomor, J.; Fabry, L.; Tordai, A.; Langer, R. M.; Masszi, T. Successful treatment of renal failure caused by multiple myeloma with HLA-identical living kidney and bone marrow transplantation: A case report. Transplant Proc. 45(10):3705-3707; 2013. 